\title{
The Alkaloid Fraction from Melicope Iatifolia Leaves Inhibits Hepatitis C Virus
}

\author{
Dwi Susiloningrum ${ }^{1}$, Adita Ayu Permanasari' ${ }^{2}$, Myrna Adianti2 ${ }^{2,3}$, Lidya Tumewu ${ }^{2}$, Tutik Sri Wahyuni ${ }^{2,4}$, Mulyadi \\ Tanjung ${ }^{2,5}$, Aty Widyawaruyanti ${ }^{2,4}$, Achmad Fuad Hafid ${ }^{2,4, *}$
}

\section{Dwi Susiloningrum ${ }^{1}$, Adita Ayu Permanasari ${ }^{2}$, Myrna Adianti ${ }^{2,3}$, Lidya Tumewu², Tutik Sri Wahyuni ${ }^{2,4}$, Mulyadi Tanjung ${ }^{2,5}$, Aty Widyawaruyanti ${ }^{2,4}$, Achmad Fuad Hafid ${ }^{2,4, *}$}

'Graduate Program of Pharmaceutical Sciences, Faculty of Pharmacy, Universitas Airlangga, Surabaya 60115, INDONESIA. ${ }^{2}$ Natural Product Medicine Research and Development, Institute of Tropical Disease, Universitas Airlangga, Surabaya 60115, INDONESIA.

${ }^{3}$ Department of Health, Traditional Medicine Study Program, Faculty of Vocational, Universitas Airlangga, Surabaya 60286, INDONESIA.

${ }^{4}$ Department of Pharmacognosy and Phytochemistry, Faculty of Pharmacy, Universitas Airlangga, Surabaya 60115, INDONESIA.

${ }^{5}$ Department of Chemistry, Faculty of Science and Technology, Universitas Airlangga, Surabaya 60115, INDONESIA.

\section{Correspondence}

\section{Achmad Fuad Hafid}

Department of Pharmacognosy and Phytochemistry, Faculty of Pharmacy, Nanizar Zaman Joenoes Building, Universitas Airlangga, Surabaya 60115 INDONESIA.

Phone no: +62-31-5933150;

Fax: +62-31-5935249;

E-mail: achmadfuad@ff.unair.ac.id; achmadfuad@yahoo.com

History

- Submission Date: 28-1-2020;

- Review completed: 13-02-2020;

- Accepted Date: 26-02-2020

DOI : 10.5530/pj.2020.12.81

Article Available online http://www.phcogj.com/v12/i3

Copyright

(C) 2020 Phcogj.Com. This is an openaccess article distributed under the terms of the Creative Commons Attribution 4.0 International license.

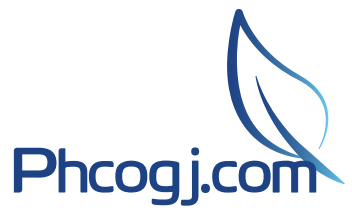

\section{ABSTRACT}

Introduction: Hepatitis C Virus (HCV) is a major health problem, which infects approximately 170 million people among worldwide population. Moreover, there is no vaccine available to prevent HCV infection and the current anti-HCV drugs have not covered all the various genotypes and subtypes. Meanwhile, medicinal plants have been widely used to treat a variety of infectious disease. Our previous study reported that ethanol extract of Melicope latifolia has been shown to exert anti-HCV activity towards a number of different virus genotypes with mainly inhibition mechanism at the entry step. Further separation was needed to purify and identify the active anti-HCV constituent using bioactivity-guided isolation method. Materials and Methods: In vitro Anti-HCV assay was performed using hepatocyte cell line (Huh7it) and HCV genotype 2a (JFH1). The purification of M. latifolia ethanol extract (B1F) was done by liquid-liquid fractionation, vacuum liquid chromatography (VLC), and high-performance liquid chromatography (HPLC). The active fraction was further identified by thin layer chromatography (TLC) and the major constituent was determined by nuclear magnetic resonance (NMR) spectra data analysis. Results: The fractionation of $M$. latifolia leaves ethanol extract resulted an alkaloid fraction (B1F D2H.3) containing a major constituent $\mathrm{N}$-methylflindersine. This alkaloid fraction was active to reduce $\mathrm{HCV}$ JFH1 with an inhibition concentration $\left(\mathrm{IC}_{50}\right)$ value of $6.21 \mu \mathrm{g} / \mathrm{mL}$, a cytotoxicity concentration $\left(\mathrm{CC}_{50}\right)$ value of $82.64 \mu \mathrm{g} / \mathrm{mL}$, and a selectivity index value of 13.31. Conclusion: An alkaloid fraction of M. latifolia (B1F D2H.3) was known to have major compound named $\mathrm{N}$-methylflindersine. This alkaloid fraction exhibited strong anti-HCV against JFH1 in vitro. The results indicated that this alkaloid fraction may a good candidate for anti-HCV agent.

Key words: Anti-HCV, Melicope latifolia, N-methylflindersine.

\section{INTRODUCTION}

Hepatitis C Virus is one of the major health problems in the world that causes millions of people to die annually. According to WHO, it was estimated that the number of deaths from hepatitis $\mathrm{C}$ is 333,000 in 1990, 499,000 in 2010 and 704,000 in 2013. The increasing number of deaths illustrates the high incidence rates of hepatitis $\mathrm{C}$ virus over the decades.

Hepatitis C Virus is an RNA virus that has a diameter of $50 \mathrm{~nm}$ and a length of $9.6 \mathrm{~kb}$. Hepatitis $\mathrm{C}$ virus is classified in the Hepacivirus genus and Flaviviridae family. This virus has varied genotypes (1-7) and more than 70 subtypes (1a, 1b, 2a, 2b etc). ${ }^{2,3}$ The viral genome encodes polyprotein precursor consisting of about 3000 amino acid residues, which is cleaved by the host and viral protease to generate 10 mature protein, structural proteins namely core E1, E2, a putative ion channel p7 and nonstructural proteins NS2, NS3, NS4, NS4B, NS5A, and NS5B. ${ }^{2}$

The recommended HCV therapy is direct-acting antiviral drugs (DAAs). Several inhibitors of viral nonstructural protein successfully improved sustained virology response (SVR) but the resistant factor, expensive price, and limited access to the treatment need to be considered as important problems. ${ }^{4,5}$ In order to circumvent those problems, the development of new antiviral drugs is very much required.

Some plants have been reported to have hepatitis C antiviral activity. Plant extracts from Toona sureni, ${ }^{6}$ Artocarpus heterophyllus, ${ }^{7}$ Ficus fistulosa, ${ }^{8}$ Alectron serratus, ${ }^{9}$ and Melicope latifolia ${ }^{4}$ significantly inhibited HCV activity in vitro. A variety of active phytochemicals such as flavonoids, terpenoids, lignins, sulphides, polyphenolics, coumarins, saponins, furyl, alkaloids, polylines, thiophenes, protein, and peptides have been identified to inhibit various viruses. ${ }^{10}$

Melicope latifolia belongs to the Rutaceae family, commonly known in Indonesia as Ki Sampang and is traditionally used to cure fever and abdominal cramps. The tree typically has a height of about 20 $\mathrm{m}$ and is commonly found in primary and secondary open forests. M. latifolia plants are distributed in Malaysia, Philippines, Java-Indonesia, KalimantanIndonesia and Papua New Guinea. ${ }^{11}$ The chemical compounds which were contained in the $M$. latifolia plant, are flavonoids, alkaloid, coumarins and terpenoids. ${ }^{10,12}$ In general, plant species in the Rutaceae family contain the chemical constituent of alkaloid group, including the Melicope genus.

Cite this article: Susiloningrum $D$, Permanasari $A A$, Adianti $M$, Tumewu L, Wahyuni TS, Tanjung $\mathrm{M}$, et al. The Alkaloid Fraction from Melicope latifolia Leaves Inhibits Hepatitis C Virus. Pharmacogn J. 2020;12(3):535-40. 
For instance, $M$. ptelefolia leaves were reported to contain the alkaloid compounds of $\mathrm{N}$-methylflindersine and two new alkaloids named melicobisquinolinone A and B. ${ }^{13}$

Our previous study showed that $80 \%$ ethanol extract of $M$. latifolia leaves exhibited potent activity as anti-HCV with $\mathrm{IC}_{50}$ of $3.5 \pm 1.4$ $\mu \mathrm{g} / \mathrm{mL}$ against $\mathrm{J} 6 / \mathrm{JFHI}$ virus by inhibiting hepatitis $\mathrm{C}$ virus mainly at the entry step. Moreover, we also reported that $M$. latifolia inhibited various genotype of HCV with a percentage inhibition of higher than $87 \%$ against all genotypes i.e $1 \mathrm{a}, 1 \mathrm{~b}, 2 \mathrm{a}, 2 \mathrm{~b}, 3 \mathrm{a}, 4 \mathrm{a}, 5 \mathrm{a}, 6 \mathrm{a}, 7 \mathrm{a} .{ }^{10}$ However, further studies to identify the active fraction which are responsible for anti-HCV activities have not been conducted yet. Therefore, this study was conducted to identify active compound from M.latifolia and analyzed their anti-HCV activity and cytotoxicity.

\section{MATERIALS AND METHODS}

\section{General}

NMR spectra were recorded on a JEOL ECS-400, using $\mathrm{CdCl}_{3}$ as the solvent. The HPLC system also includes two LC-10AD pumps and a SCL-10A controller. An Agilent RP-18 XDB column 4.6 x $250 \mathrm{~mm}$ was eluted with $\mathrm{CH}_{3} \mathrm{CN}-\mathrm{H}_{2} \mathrm{O}(7: 3 \mathrm{v} / \mathrm{v})$ at $2 \mathrm{~mL} /$ minute of flow rate. Vacuum Liquid Chromatography (VLC) on silica gel $\mathrm{GF}_{254}$ (Merck, Cat No. 1.07730.0500) and Thin Layer Chromatography (TLC) was carried out on silica gel $60 \mathrm{~F}_{254}$ (Merck, Cat No. 1.05715.0001) and RP-18 silica gel plate (Merck, Cat No. 1.15389.0001). The identification of TLC profile was performed using TLC Visualizer (Camag).

\section{Plants material}

M. latifolia leaves were collected from Salak Mountain (900 ma.s.l.), West Java, Indonesia. The species was determined and identified by Purwodadi National Botanical Garden-Indonesia Institute of Science, Malang, East Java (No. of determination: 0340/IPH.06/HM/III/2017).

Extraction, fractionation, and identification of major compound

M. latifolia leaves were dried at room temperature then extracted using $80 \%$ ethanol by ultrasonic assisted extraction for two minutes at three times of replications. The M.latifolia ethanol extract (B1F) was further fractionated by liquid-liquid fractionation using dichloromethanewater to obtain dichloromethane fraction (B1F D). Further separation of B1F D by vacuum liquid chromatography using a gradient solvent of chloroform-methanol (100\%-97\%) resulted in 9 subfractions (B1F D1-D9). The anti-HCV active subfraction (B1F D2) was then separated by semi preparative HPLC using acetonitrile : water $(7-3 \mathrm{v} / \mathrm{v}), 2 \mathrm{~mL} /$ min of flow rate and resulted 5 subfractions (B1F D2H.1-B1F D2H.5). The active subfraction profile was analyzed using silica gel $60 \mathrm{~F}_{254}$ plate, scanned by TLC Visualizer on UV $254 \mathrm{~nm}$ and $366 \mathrm{~nm}$, and sprayed with dragendorf, a specific reagent for alkaloid compound. The chemical structure of active subfraction was identified using NMR-JEOL ECS400 and the spectra were then analyzed using MNova program.

\section{Anti-HCV activity and cytotoxicity assay}

\section{Cell culture preparation}

Huh7it cells were cultivated in DMEM (Dulbeco's Modified Eagle Medium) (GIBCO Invitrogen) and supplemented with 10\% Fetal Bovine Serum (FBS), 1x Non-Essential Amino Acids (NEAA, GIBCO Invitrogen) $5 \mathrm{~mL}$, and $0.15 \mathrm{mg} / \mathrm{mL}$ Kanamycin solution (SIGMA) in $5 \% \mathrm{CO}_{2}$ at $37^{\circ} \mathrm{C}$. The culture condition of Huh7it cells was observed under a microscope every day. The passage was performed while cells confluent $>80 \%{ }^{7}$

\section{HCV propagation}

HCV genotype 2a (JFH1) propagation was performed on hepatocyte Huh7it cells ( $1.8 \times 10^{7}$ cells). Infected cells were incubated at $37^{\circ} \mathrm{C}$ in $5 \%$ $\mathrm{CO}_{2}$ for 4 hours with agitation every 30 minutes. HCV supernatants were harvested on day 3 and were concentrated through an Amicon Ultra- 15 centrifugal filter (Millipore) by centrifugation at $3500 \mathrm{rpm}, 15$ min, $4{ }^{\circ} \mathrm{C}$. DAB staining was used to visualize infected cells for virus titration. $^{7}$

\section{Cytotoxicity assay}

The cytotoxicity analysis of the sample was assessed by MTT assay. Huh7it cells in 96 well plates were treated with serial dilution of the sample or control. The condition of the cells was observed after 48 hours incubation and the toxicity was checked under microscope. The medium was removed from 96 well plates and then MTT 10\% 150 $\mu \mathrm{l} /$ well was put by multichannel pipette and incubated for 4 hours at $37^{\circ} \mathrm{C}$. MTT solution was removed from 96 well plates and 1 DMSO 100\% was added to dissolve formazan. The absorbance of sample was measured at $560 \mathrm{~nm}$ and $750 \mathrm{~nm}$. The percentage of inhibition was calculated by comparing the absorbance sample with control. Probit analysis was conducted to calculate the $\mathrm{CC}_{50}{ }^{7}$

\section{Analysis of anti-HCV activities}

Extract and fraction of $M$. Latifolia were dissolved in dimethyl sulfoxide (DMSO) to obtain a stock solution at the concentration of $100 \mathrm{mg} / \mathrm{mL}$. The stock solution was stored at $-20^{\circ} \mathrm{C}$ until it was used. Huh7it cells were plated in 48 -well plates ( $5 \times 10^{4}$ cells/well). A fixed amount of JFH1, with multiplication infection (MOI) of 0.1 was infected onto Huh7it cell then treated with the presence of extract and fraction of M. latifolia. The virus infected cells were stained with $\mathrm{DAB}$ thermo staining and calculated under microscope.

\section{Data analysis}

The $50 \%$ growth inhibition $\left(\mathrm{IC}_{50}\right)$ and cytotoxicity $\left(\mathrm{CC}_{50}\right)$ was determined using an SPSS probit analysis by creating a curve relationship between the percentage of inhibition or cytotoxicity and the logs of doses.

\section{RESULTS}

\section{Fractionation and identification of major compound}

The fractionation of B1F D2 separated by semi preparative HPLC using acetonitrile: water $(7-3 \mathrm{v} / \mathrm{v}), 2 \mathrm{~mL} / \mathrm{min}$ of flow rate and resulted 5 subfractions (B1F D2H.1-B1F D2H.5). From those 5 subfractions, the most active subfraction was B1F D2H.3. Identification of B1F D2H.3 by HPLC was indicated that it was contain a major compound with a purity of $85.25 \%$ (Figure 1).

The chromatogram profile of B1F D2H.3 using stationary phase column 4.6x250 mm agilent RP-18 XDB, acetonitrile-water mobile phase 7:3 $\mathrm{v} / \mathrm{v}$, and flow rate $0.5 \mathrm{~mL} /$ minute. It showed the alkaloid fraction (B1F D2H.3) contain N-methylflindersine detected at etention time (Rt) $14.195 \mathrm{~min}$ and had $85.25 \%$ purity (Figure 2).

The results of ${ }^{1} \mathrm{H}-\mathrm{NMR}$ and C-NMR of B1F D2H.3 showed the ${ }^{1}$ $\mathrm{H}-\mathrm{NMR}\left(\mathrm{CDCl}_{3} 400 \mathrm{MHz}\right) ; \mathrm{H} 5.53(1 \mathrm{H}, \mathrm{d}, J=10.0 \mathrm{~Hz}, \mathrm{H}-3), 6.75(1 \mathrm{H}$, d, $J=10.0 \mathrm{~Hz}, \mathrm{H}-4), 7.32(1 \mathrm{H}, \mathrm{d}, J=8.5, \mathrm{H}-7), 7.54(1 \mathrm{H}, \mathrm{dt}, J=7.4 \mathrm{~Hz}$, H-8), $7.21(1 \mathrm{H}, \mathrm{t}, J=7.9 \mathrm{~Hz}, \mathrm{H}-9), 7.96(1 \mathrm{H}, \mathrm{dd}, J=7.9 \mathrm{~Hz}, \mathrm{H}-10), 1.52$ $(6 \mathrm{H}, \mathrm{s}, 2-\mathrm{Me}), 1.52(6 \mathrm{H}, \mathrm{s}, 2-\mathrm{Me}), 3.69(3 \mathrm{H}, \mathrm{s}, \mathrm{N}-\mathrm{Me})$ and ${ }^{13} \mathrm{C}-\mathrm{NMR}$ $\left(\mathrm{CDCl}_{3} 400 \mathrm{MHz}\right): \delta 78.3(\mathrm{C}-2), 126.4(\mathrm{C}-3), 118.0$ (C-4), 105.9 (C-4a), 160.5 (C-5), 139.4 (C-6a), 114.1 (C-7), 130.9 (C-8), 121.7 (C-9), 123.2 (C-10), 115.2 (C-10a), 155.2 (C-10b), 28.3 (2-Me), 29.2 (N-Me). The ${ }^{1} \mathrm{H}-\mathrm{NMR}$ spectrum $\left(\mathrm{CDCl}_{3}, 400 \mathrm{MHz}\right)$ showed four aromatic proton signals ortho, meta and para $[\delta \mathrm{H} 7.96(1 \mathrm{H}, \mathrm{dd}, \mathrm{J}=7.9 \mathrm{~Hz}, \mathrm{H}-10), 7.54$ 
$(1 \mathrm{H}, \mathrm{dt}, \mathrm{J}=7.4 \mathrm{~Hz}, \mathrm{H}-8), 7.32(1 \mathrm{H}, \mathrm{d}, \mathrm{J}=8.5 \mathrm{~Hz}, \mathrm{H}-7), 7.21(1 \mathrm{H}, \mathrm{t}, \mathrm{J}=$ $7.9 \mathrm{~Hz}, \mathrm{H}-9)$ ], which is the characteristic of substituted 1.2 benzene. ${ }^{13}$ A pair of cis-vinylic doublet signals $(\mathrm{J}=10.0 \mathrm{~Hz})$ at $\delta \mathrm{H} 6.75(\mathrm{H}-4)$ and $5.53(\mathrm{H}-3)$ and one methyl signal at $\delta \mathrm{H} 1.53\left(11-\mathrm{CH}_{3}\right.$ and $\left.12-\mathrm{CH}_{3}\right)$ are proton signals from group 2, 2-dimethylpirano. ${ }^{14}$ The singlet signal at $\delta \mathrm{H} 3.69\left(\mathrm{~N}-\mathrm{CH}_{3}\right)$ is a proton signal of $\mathrm{N}$-methyl. The NMR spectral data were identical with those in references, ${ }^{13}$ and TLC analysis of subfraction B1F D2H.3 showed an orange spot with a dragendorf reagent (Figure 3). The result showed that B1F D2H.3 was similar as alkaloids $N$-methylflindersine.

\section{Anti-HCV activity}

The fraction and subfractions were subjected in vitro anti-HCV and cytotoxicity assay. First fraction (B1F D), and subfractions (B1F D1-B1F D9) were tested at a concentration of $30 \mu \mathrm{g} / \mathrm{mL}$. The result showed that subfractions B1F D2, B1F D7, and B1F D9 exhibited strong activity against hepatitis $\mathrm{C}$ virus with inhibition percentages of $97.05 \%, 98.31 \%$,and $98.30 \%$, respectively. On the other hand, the same concentration of B1F D1, B1F D3-D6, and B1F D8 showed lower antiHCV activity with percentage inhibition less than $28 \%$. To determine the cytotoxicity effect, MTT test was performed in Huh7it. The results showed no toxic effect among all subfractions with mediated the cell viability higher than $85 \%$, while the active subfractions B1F D2, B1F D7 and B1F D9 had viability levels of $99.77 \%$, 93.63\%, and $95.99 \%$, respectively (Table 1 ).

To determine the $\mathrm{IC}_{50}$ value, the active fraction and subfractions were evaluated for their inhibition percentages at various concentrations. The result showed that B1F D, B1F D2, B1F D7 and B1F D9 exhibited strong anti-HCV activity with an $\mathrm{IC}_{50}$ value of $11.38 \mu \mathrm{g} / \mathrm{mL}, 13.33 \mu \mathrm{g} / \mathrm{mL}, 4.5$ $\mu \mathrm{g} / \mathrm{mL}$, and $2.9 \mu \mathrm{g} / \mathrm{mL}$, respectively. The cytotoxicity assay revealed that

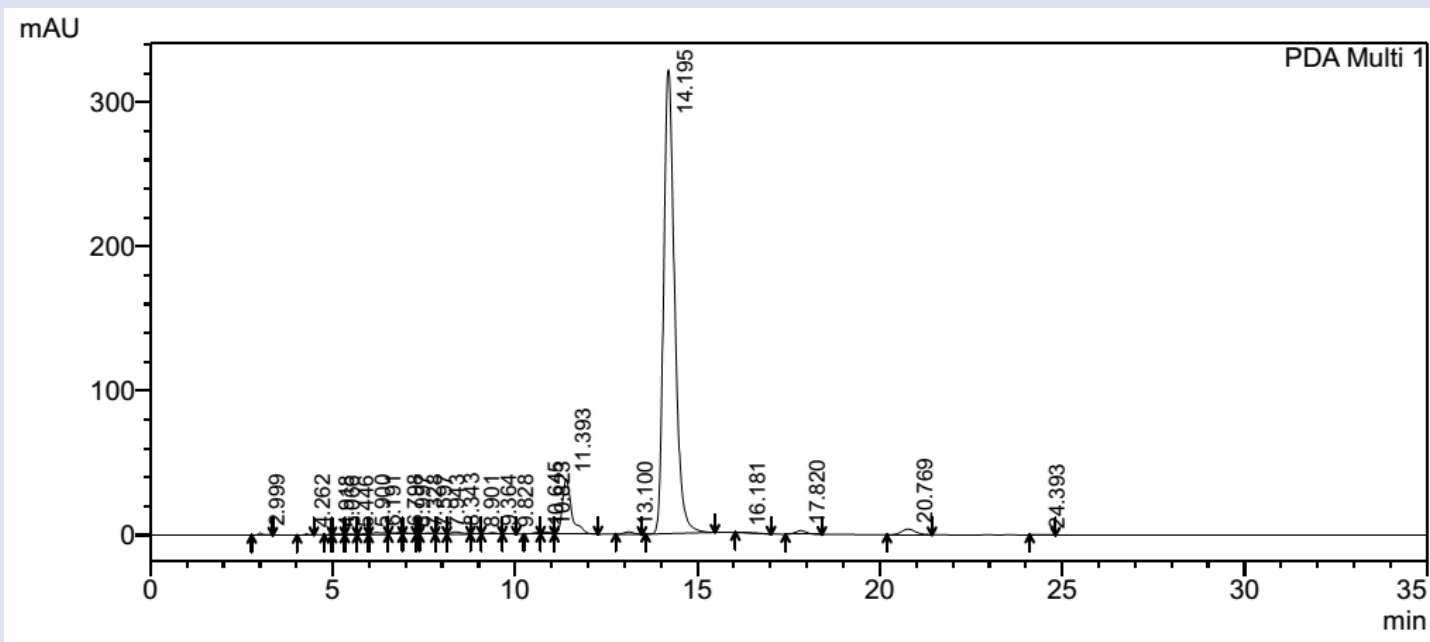

Figure 1: HPLC Chromatogram of B1F D2H.3.

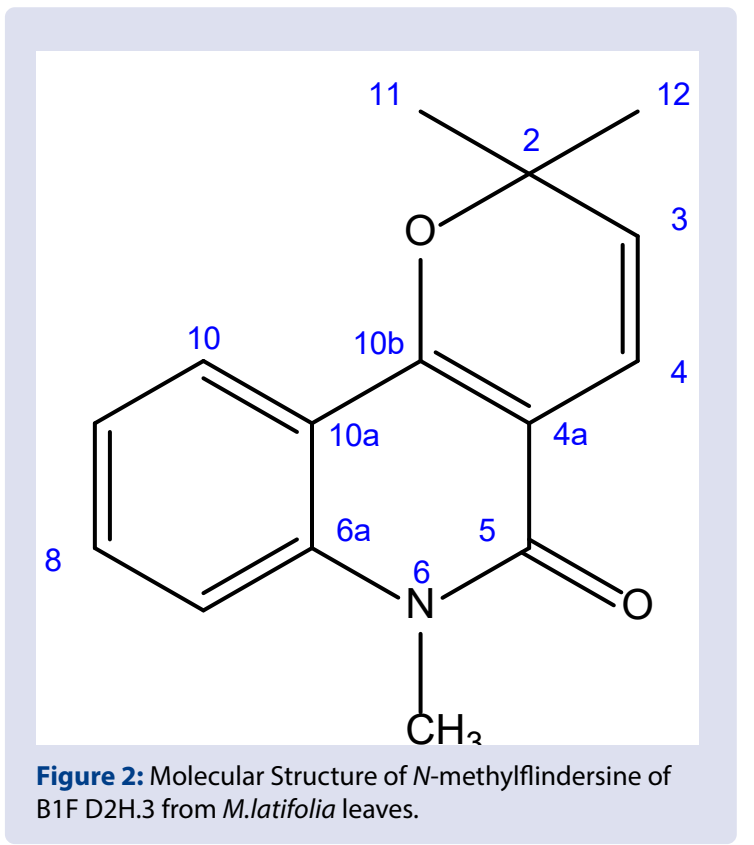


all active fractions mediate $\mathrm{CC}_{50}$ value of $>100 \mu \mathrm{g} / \mathrm{mL}$. There was no cytotoxicity with exposure of sample up to $100 \mu \mathrm{g} / \mathrm{mL}$ for $48 \mathrm{~h}$. The selectivity index (SI) that determined the effectiveness of a potential medicinal drug was analyzed by the ratio of $\mathrm{CC}_{50}$ and $\mathrm{IC}_{50}$ It was shown that the highest SI value of $>96.56$ belongs to subfraction B1F D9 followed with B1F D7 and B1F D2 (Table 2). Due to a high amount of chlorophyl on B1F D7 and B1F D9, we focused to further separate B1F D2 using semi preparative HPLC to obtain the subfraction.

We obtained 5 subfractions (B1F D2H.1-B1F D2H.5) and analyzed their activity and toxicity as anti-HCV. The results determined that B1F D2H.3 had a strong active anti-HCV activity with an $\mathrm{IC}_{50}$ value of $6.29 \mu \mathrm{g} / \mathrm{mL}$, a $\mathrm{CC}_{50}$ value of $82.64 \mu \mathrm{g} / \mathrm{mL}$, and an SI $>13.31$ (Table 3). This result showed that subfraction D2H.3 may a potential target for separating the active anti-HCV constituent.

\section{DISCUSSION}

Developing anti-HCV agents from medicinal plants has become a currently significant issue. In recent years, many compounds were isolated from medicinal plants reported to be active anti-HCV agents. Chalepin and pseudane IX from Ruta angustifolia (leaves) revealed anti-HCV activities with $\mathrm{IC}_{50}$ value of $1.7 \pm 0.5$ and $1.4 \pm 0.2 \mu \mathrm{g} / \mathrm{mL}$ by inhibiting $\mathrm{HCV}$ replication and decreasing the NS3 protein level, ${ }^{15}$ Embelin and 5-O-Methyl embelin were isolated from Embelia schimper (Fruit) with $\mathrm{IC}_{50}$ of $21 \mu \mathrm{M}$ and $46 \mu \mathrm{M}$, by inhibiting HCV replication and decreasing the NS3 protein level, ${ }^{16}$ and Saikosaponin b2 from Bupleurum kaoi root with $\mathrm{IC}_{50} 16.1 \mu \mathrm{g} / \mathrm{mL}$ inhibited HCV by the neutralization of virus particle, attachment, and fusion. ${ }^{17}$
Anti-HCV activity and the mechanism of action from the ethanol extract of $M$. latifolia leaves had been reported in previous studies. ${ }^{10}$ In this study, we have fractionated and identified the active compound as anti-HCV agent from M. latifolia. The active fraction was contained major compound which similar with a known alkaloid compound called $\mathrm{N}$-methylflindersine. This fraction has anti-HCV activity with $\mathrm{IC}_{50}$ value of $6.2 \mu \mathrm{g} / \mathrm{mL}$ and less cytotoxicity effect with $\mathrm{CC}_{50}$ value of $82.64 \mu \mathrm{g} / \mathrm{mL}$.

$\mathrm{N}$-methylflindersine is the characteristic constituent of Rutaceae and Meliaceae families. It is known to possess insect growth inhibitor, antifeedant, and fungistatic activities. ${ }^{13,18}$ The antiviral activity of $\mathrm{N}$-methylflindersine in M.latifolia has not been reported yet.

Melicope species have been investigated for their chemical compounds. Melicope ptelefolia leaves were reported to contain $\mathrm{N}$-methylflindersine and two new alkaloids named melicobisquinolinone $\mathrm{A}$ and $\mathrm{B}$. Another alkaloid were obtained from Melicope semicarfolia, there were 2-acetylevolitrine (1), 2-acetylpteleine (2), and semecarpifoline (3). Several of these alkaloid exhibited significant antiplatelet aggregation activities in vitro. ${ }^{19}$ There was APS, an alkaloid from Maytrenus ilicifolia (root bark), which has known activity as anti$\mathrm{HCV}$ with $\mathrm{EC}_{50}$ of $2.3 \mu \mathrm{M}$ by decreasing HCV replication and NS5A level. ${ }^{20}$ Although the mechanism of ethanol extract from M.latifolia was known to inhibit mainly at the entry step with $90.8 \pm 0.2 \%$ and post entry step $60.6 \pm 4.9 \%$, the mechanism of action of its alkaloid fraction, $\mathrm{N}$-methylflindersine was still unknown. Further analysis of the mechanism of $\mathrm{N}$-methylflindersine was necessary.

\begin{tabular}{|c|c|c|}
\hline Sample Code & Inhibition (\%)* & Cell Viability $(\%)^{*}$ \\
\hline B1F D & $78.25 \pm 1.49$ & $87.65 \pm 5.32$ \\
\hline B1F D1 & $0 \pm 0$ & $96.42 \pm 2.39$ \\
\hline B1F D2 & $97.05 \pm 0.35$ & $99.77 \pm 0.88$ \\
\hline B1F D3 & $3.91 \pm 0.49$ & $94.11 \pm 3.54$ \\
\hline B1F D4 & $27.14 \pm 1.98$ & $85.70 \pm 0.89$ \\
\hline B1F D5 & $40.68 \pm 0.97$ & $90.98 \pm 3.24$ \\
\hline B1F D6 & $0.13 \pm 0.18$ & $99.78 \pm 1.28$ \\
\hline B1F D7 & $98.31 \pm 2.39$ & $93.63 \pm 3.68$ \\
\hline B1F D8 & $24.89 \pm 0$ & $97.23 \pm 3.80$ \\
\hline B1F D9 & $98.30 \pm 2.40$ & $95.99 \pm 0.88$ \\
\hline
\end{tabular}

*values are Mean \pm SD of duplicates experiments

Table 2: Antiviral activity $\left(\mathrm{IC}_{50}\right)$, cytotoxicity $\left(\mathrm{CC}_{50}\right)$, and selectivity index (SI) of fraction and subfraction of $M$. latifolia leaves.

\begin{tabular}{cccc}
\hline Sample & $\mathrm{IC}_{50}(\mu \mathrm{g} / \mathrm{mL})$ & $\mathrm{CC}_{50}(\mu \mathrm{g} / \mathrm{mL})$ & SI (Selectivity Index) \\
\hline B1F D & 11.16 & 171.03 & $>15.33$ \\
B1F D2 & 13.38 & 142.85 & $>10.68$ \\
B1F D7 & 4.47 & 295.41 & $>66.09$ \\
B1F D9 & 2.89 & 280.03 & $>96.90$ \\
\hline
\end{tabular}

Table 3: Antiviral activity $\left(\mathrm{IC}_{50}\right)$, cytotoxicity $\left(\mathrm{CC}_{50}\right)$, and selectivity index (SI) of subfraction from M. Iatifolia leaves.

\begin{tabular}{cccc}
\hline Sample & $\mathrm{IC}_{50}(\mu \mathrm{g} / \mathrm{mL})$ & $\mathrm{CC}_{50}(\mu \mathrm{g} / \mathrm{mL})$ & $\mathrm{SI}$ (Selectivity Index) \\
\hline B1F D2H.1 & 79.34 & 349.91 & $>4.40$ \\
B1F D2H.2 & 252.51 & $>1000$ & $>3.96$ \\
B1F D2H.3 & 6.21 & 82.64 & $>13.31$ \\
B1F D2H.4 & 27.18 & 171.07 & $>6.29$ \\
B1F D2H.5 & 71.20 & 699.86 & $>9.83$ \\
\hline
\end{tabular}




\section{CONCLUSION}

This study identified the potential of alkaloid fraction from M.latifolia as an anti-HCV agent. $N$-methylflindersine was identified as active anti-HCV fraction with a major constituent purity of $85.25 \%$. These results suggest that M.latifolia and alkaloid fraction might be a good candidate to develop anti-HCV agents.

\section{CONFLICTS OF INTEREST}

The authors declare that they have no competing interest.

\section{ACKNOWLEDGEMENTS}

This research was supported by Mandat Research Grant funding year 2016 from Universitas Airlangga, and NPMRD (Natural Product Medicine Research and Development), Institute of Tropical Disease, Universitas Airlangga, Indonesia, funding year 2018.

\section{REFERENCES}

1. WHO: Guidelines for the Screening, Care, and Treatment of Persons With Hepatitis C Infection. In. Geneva; 2016.

2. Apriyanto DR, Aoki C, Hartati S, Hanafi M, Kardono LB, Arsianti A, et al. AntiHepatitis C Virus Activity of a Crude Extract from Longan (Dimocarpus longan Lour.) Leaves. Japanese Journal of Infectious Diseases. 2016;69(3):213-20.

3. Lange CM, Jacobson IM, Rice CM, Zeuzem S. Emerging therapies for the treatment of hepatitis C. EMBO Molecular Medicine. 2014;6(1):4-15.

4. Wahyuni TS, Aoki C, Hotta H. Promising Anti-Virus hepatitis C Compounds from Natural Resources. Natural Product Communications. 2016;11(8):1193-200.

5. Pawlotsky JM, Negro F, Aghemo A, Back D, Dusheiko G, Forns X. EASL Recommendations of Treatment of Hepatitis C. Journal of Hepatology. 2016;123.

6. Hafid AF, Wahyuni TS, Tumewu L, Apryani E, Permanasari AA, Adianti M, et al. Antihepatitis C Virus Activity of Indonesian Mahogany (Toona Sureni). Asian Journal of Pharmaceutical and Clinical Research. 2018;11(2):87-90.

7. Hafid AF, Utsubo CA, Permanasari AA, Adianti M, Tumewu L, Widyawaruyanti A, et al. The dichloromethane extract from Artocarpus heterophyllus leaves against hepatitis C virus. Asian Pasific Journal of Tropical Biomedicine. 2017;8:79-84.
8. Hafid AF, Permanasari AA, Tumewu L, Adianti M, Widyawaruyanti A, Soetjipto, et al. Activities of Ficus fistulosa hepatitis $C$ virus leaves extract and fractions against hepatitis C virus. Procedia Chemistry. 2016;18:179-84.

9. Tumewu L, Apryani E, Santi MR, Wahyuni TS, Permanasari AA, Adianti M, et al. Antihepatitis $C$ virus activity of Alectryon serratus leaves extract. Procedia Chemistry. 2016;18:169-73

10. Wahyuni TS, Tumewu L, Permanasari AA, Apriani E, Adianti M, Rahman A, et al Antiviral activities of Indonesian medicinal plants in the East Java region against hepatitis C virus. Virology Journal. 2013;10:259.

11. K.M W, Soepadmo E. Tree Flora of Sabah and Serawak, vol. 2. Malaysia: Sabah Foresty Departement. 2002.

12. Li S, Tian H, Ye WC, Jian RW. Benzopyrans and furoquinoline alkaloids from Melicope ptelefolia. Biochem Sys Ecol. 2011;39:64-7.

13. Kamperdick CV, Van NH, Sung TV, Adam G. Bisquinoline alkaloids from Melicope ptefolia. Phytochemistry Journal. 1999;50:177-81.

14. Tanjung M, Rachmadiarti F, Prameswari A, Agyani VUW, Saputri RD, Tjahjandarie TS, et al. Airlanggins A-B, two new isoprenylated benzofuran-3-ones from the stem bark of Callophyllum soulattri. Natural Product Research. 2017;1-6.

15. Wahyuni TS, Widyawaruyanti A, Lusida MI, Fuad A, Soetjipto, Fuchino H, et al. Inhibition of hepatitis $C$ virus replication by chalepin and pseudane IX isolated from Ruta angustifolia leaves. Fitoterapia. 2014;99:276-83.

16. Hussein G, Miyashiro H, Nakamura N, Hattori M, Kakiuchi N, Shimotohno K. Inhibitory effects of sudanese medicinal plant extracts on hepatitis $\mathrm{C}$ virus (HCV) protease. Phytotherapy Research : PTR. 2000;14(7):510-6.

17. LIn T, Chung CY, Hsu WC, Chang SP, Hung TC, Shield J, et al. Saikosaponin b2 is a natural occurring terpenoid that efficiently inhibits hepatitis $C$ virus entry. Journal of Hepatology. 2015;159:89-97.

18. Hagnauer R. Chemotaxonomie der Pflanzen, Band IX. Birkhauser Basel. 1990;38:449.

19. Chen IS, Chen HF, Cheng MJ, Chang YL, Teng CM, Tsutomu I, et al. Quinoline alkaloids and other constituents of Melicope semecarpifolia with antiplatelet aggregation activity. Journal of Natural Products. 2001;64(9):1143-7.

20. Jardim AC, Igloi Z, Shimizu JF, Santos VA, Felippe LG, Mazzeu BF, et al. Natura compounds isolated from Brazilian plants are potent inhibitors of hepatitis $C$ virus replication in vitro. Antiviral Research. 2015;115:39-47.

\section{GRAPHICAL ABSTRACT}

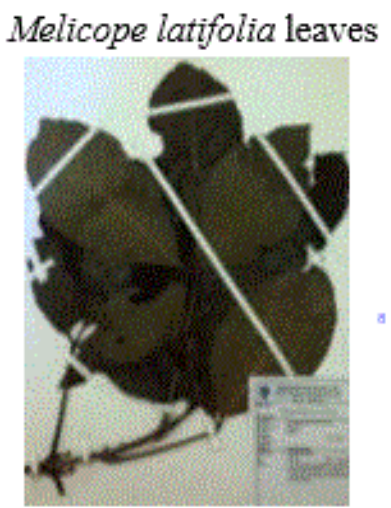<smiles>Cn1c(=O)c2c(c3ccccc31)OC(C)(C)C=C2</smiles>

$\mathrm{N}$-methylflindersine

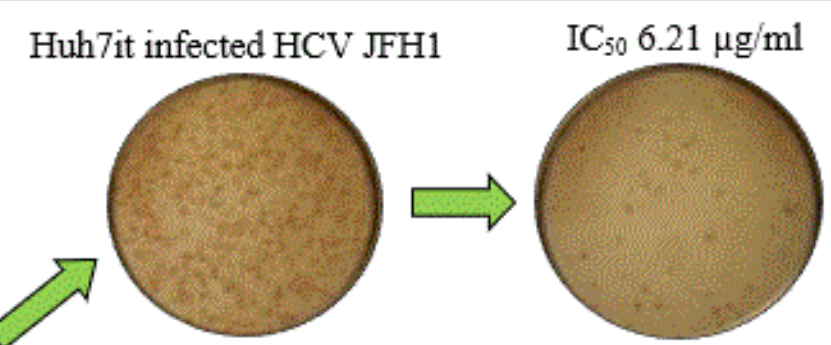

MTT assay $\left(\mathrm{CC}_{50} 82.64 \mu \mathrm{g} / \mathrm{ml}\right)$

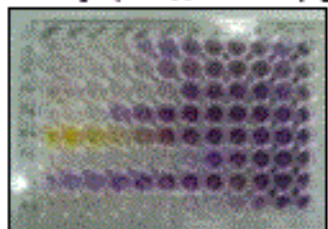




\section{ABOUT AUTHORS}

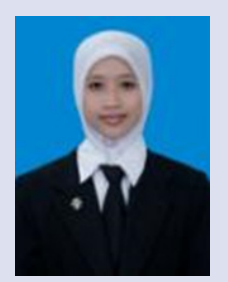

Dwi Susiloningrum obtained her bachelor's degree in pharmacy at Faculty of Pharmacy, Muhammadiyah University of Surakarta in 2012. In 2013, she pursued her Pharmacists tittle and started to obtain her master's degree in Natural Product Chemistry, Pharmaceutical Science at Universitas Airlangga in the following year. Now she is focuses on study of the secondary metabolite as anti Hepatitis C Virus.

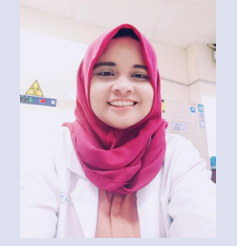

Adita Ayu Permanasari is a researcher in Institute of Tropical Disease, Universitas Airlangga, Indonesia. She graduated in Master of Biology from Faculty of Science and Technology, Universitas Airlangga. She is currently work on antihepatitis virus cell culture and its mechanism of action. Some studies of hepatitis viruses have been published in some international scientific journals.

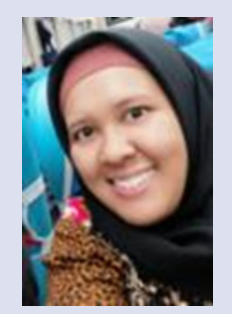

Myrna Adianti obtained her bachelor's degree in biology at Faculty of Science and Technology, Universitas Airlangga. She was continued to obtain her master's degree at Faculty of Medicine, Universitas Airlangga. She pursued her PhD at Kobe University, Japan. She is currently a lecturer at Faculty of Vocational Study, Universitas Airlangga and a researcher at Institute of Tropical Disease, Universitas Airlangga. Her major achievement are in the field of bioactivity including antiHepatitis $\mathrm{C}$ virus activity and antiamebic activity using cell culture.

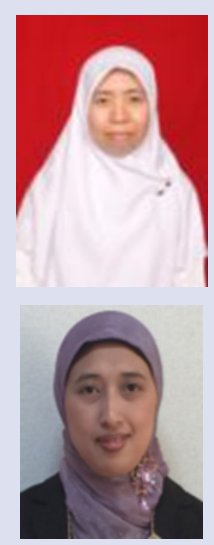

Lidya Tumewu obtained Bachelor and master's degree in pharmacy at Faculty of Pharmacy, Universitas Airlangga. She is a researcher at Institute of Tropical Disease, Universitas Airlangga. She is focuses on metabolite secondary of natural product and their bioactivity.

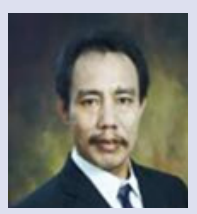

Mulyadi Tanjung is a lecturer at Faculty of Science and Technology, Universitas Airlangga. He was graduated as Bachelor of Chemistry from Andalas University. He was further obtain his Master and Doctoral degree at Institute of Technology Bandung. His major achievements are in the field of isolation and identification of compounds from endemic plants of Indonesia especially East area of Indonesia.

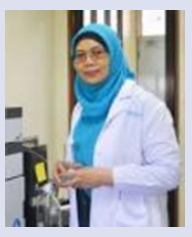

Aty Widyawaruyanti is a lecturer at Faculty of Pharmacy, Universitas Airlangga and researcher at Natural Product Medicine Research and Development (NPMRD), Institute of Tropical Disease, Universitas Airlangga. She obtained her bachelor's degree in pharmacy at Faculty of Pharmacy, Padjajaran University. She was further persued her Master and Doctoral degree at Faculty of Pharmacy, Universitas Airlangga. Her research is focuses on drug discovery from bioactive natural products especially drug discovery for antimalarial drugs.

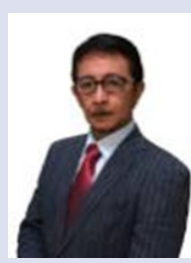

Achmad Fuad Hafid is currently vice-director of Institute of Tropical Disease, Universitas Airlangga. He is a lecturer at Faculty of Pharmacy, Universitas Airlangga and a researcher as well. His acquired a Professor with expertise in the fields of phytochemistry and bioactive natural product discovery for therapeutic applications.

Cite this article: Susiloningrum D, Permanasari AA, Adianti M, Tumewu L, WahyuniTS, Tanjung M, et al. The Alkaloid Fraction from Melicope latifolia Leaves Inhibits Hepatitis C Virus. Pharmacogn J. 2020;12(3):535-40. 